\title{
Prevalence of Panulirus argus Virus 1 (PaV1) and habitation patterns of healthy and diseased Caribbean spiny lobsters in shelter-limited habitats
}

Enrique Lozano-Álvarez ${ }^{1, *}$, Patricia Briones-Fourzán ${ }^{1}$, Aurora Ramírez-Estévez $^{2}$,
David Placencia-Sánchez ${ }^{1}$, Juan Pablo Huchin-Mian ${ }^{3}$, Rossana Rodríguez-Canul

${ }^{1}$ Instituto de Ciencias del Mar y Limnología, Unidad Académica Puerto Morelos, Universidad Nacional Autónoma de México, Prol. Av. Niños Héroes s/n, Puerto Morelos, Quintana Roo, 77580 Mexico

${ }^{2}$ Centro Regional de Investigación Pesquera-Puerto Morelos, Instituto Nacional de la Pesca, Prol. Av. Niños Héroes, Calle Matamoros esq. Hidalgo No. 7, Puerto Morelos, Quintana Roo, 77580 Mexico

${ }^{3}$ Laboratorio de Inmunología y Biología Molecular, Centro de Investigación y de Estudios Avanzados-Unidad Mérida, Instituto Politécnico Nacional, Km 6 Carretera Antigua a Progreso, Cordemex, Mérida, Yucatán, 97310 Mexico

\begin{abstract}
Caribbean spiny lobsters Panulirus argus are socially gregarious, preferring shelters harboring conspecifics over empty shelters. In laboratory trials, however, healthy lobsters strongly avoided shelters harboring lobsters infected with the highly pathogenic Panulirus argus Virus 1 (PaV1). Because PaV1 is transmitted by contact, this behavior may thwart its spread in wild lobsters. In a field experiment conducted from 1998 to 2002 in a shelter-poor reef lagoon (Puerto Morelos, Mexico), densities of juvenile $P$. argus increased significantly on sites enhanced with artificial shelters (casitas) but not on control sites. Because PaV1 emerged in this location during 2000, we reexamined these data to assess whether casitas could potentially increase transmission of PaV1. In 2001, PaV1 prevalence was 2.5\% and the cohabitation level (percentage of healthy lobsters cohabiting with diseased lobsters) was similar between natural shelters (3.5\%) and casitas (2.4\%). The relative lobster densities in casita sites and control sites did not change significantly before (1998-1999) or after (2001-2002) the disease emergence. In late 2006, data from casita sites showed a significant increase in prevalence $(10.9 \%)$ and cohabitation level $(29.4 \%)$, but no significant changes in lobster density. In May 2006, casitas were deployed on shelter-poor sites within Chinchorro Bank, 260 km south of Puerto Morelos. In late 2006, prevalence and cohabitation level were 7.4 and $21.7 \%$, respectively. Our results are inconclusive as to whether or not casitas increase PaV1 transmission, but suggest that across shelter-poor habitats, lobsters make a trade-off between avoiding diseased conspecifics and avoiding predation risk.
\end{abstract}

KEY WORDS: Casitas · Mexican Caribbean · Panulirus argus Virus 1 - PaV1 • Prevalence · Spiny lobster

Resale or republication not permitted without written consent of the publisher

\section{INTRODUCTION}

Wild spiny lobsters (Palinuridae) have few reported infectious diseases (Evans et al. 2000). In particular, viral infections in spiny lobsters had not been conclusively demonstrated until Shields \& Behringer (2004) discovered that Panulirus argus Virus 1 (PaV1) was the causative agent of an emergent disease affecting Caribbean spiny lobsters Panulirus argus (Latreille,
1804) in Florida Bay, USA, since 1999. PaV1 mainly affects young lobsters (Behringer et al. 2001, 2006) and is highly pathogenic, as shown by mortalities near $100 \%$ within 30 to $80 \mathrm{~d}$ in experimentally infected juvenile lobsters (Shields \& Behringer 2004). The virus infects hyalinocytes and semigranulocytes in the hemolymph and the spongy soft connective tissues of the hepatopancreas and other organs, leading to metabolic wasting in heavily infected lobsters (Shields \& 
Behringer 2004, Li \& Shields 2007, Huchin-Mian et al. 2008). Signs of gross infection include lethargy, morbidity, a pink discoloration of the white markings over the carapace, suppression of molt, and a thin milky hemolymph that does not clot. In particular, the change in aspect of the hemolymph, from clear or bluish to a white milky color, is diagnostic for infection (Montgomery-Fullerton et al. 2007).

There is great concern about the potential effects of a spread of the PaV1 disease because Panulirus argus sustains important fisheries throughout the greater Caribbean region (Lipcius \& Eggleston 2000). Laboratory trials (Butler et al. 2008) have shown that PaV1 is mainly transmitted through contact between healthy and diseased lobsters, and to a lesser extent through ingestion of diseased tissue and through water, at least over distances of a few meters. Although other potential transmission mechanisms (e.g. larval transport, movements of potential carriers, and/or anthropogenic introductions) cannot as yet be dismissed, life history features of Panulirus argus may increase the potential for contact transmission of PaV1 in wild lobsters. After a short, asocial algal-dwelling phase ('algal' juveniles, 6 to 15-25 mm carapace length, CL), lobsters shift to using daytime crevice-type shelters ('dens'), where they tend to aggregate. Den sharing is shown by all the crevicedwelling phases ('postalgal juveniles', 15-25 to 35-45 mm CL; subadults, 35-45 to $80 \mathrm{~mm} \mathrm{CL;} \mathrm{and}$ adults, 80 to $<200 \mathrm{~mm}$ CL) (Childress \& Herrnkind 1996). As they grow, lobsters also undergo several habitat shifts, from shallow lagoon and bay areas to coral reef habitats to depths of $\sim 100 \mathrm{~m}$, and their nocturnal foraging ranges tend to increase, from a few to several hundreds of meters away from their dens (Lipcius \& Eggleston 2000).

Den sharing by Panulirus argus, which is mediated by conspecific chemical attraction (Ratchford \& Eggleston 1998, Nevitt et al. 2000), has an adaptive value because it reduces predation risk of individual lobsters through either a 'guide effect', a 'dilution effect', or 'group defense' (Childress \& Herrnkind 2001, Dolan \& Butler 2006). In natural habitats across Florida Bay, Behringer et al. (2006) observed that more healthy lobsters shared dens than resided alone, whereas more lobsters infected with PaV1 dwelled solitarily. In laboratory trials, healthy lobsters, but not diseased lobsters, showed a strong tendency to avoid dens harboring an infected conspecific (Behringer et al. 2006). Behringer et al. (2006) suggested that avoidance of diseased lobsters by healthy conspecifics may act to thwart the spread of the disease and may partially explain the low yearly PaV1 prevalences on their sampling sites across Florida Bay since 2000 (6 to 8\%).

Shelter for juvenile Panulirus argus is usually more abundant on shallow hard bottoms than over soft bot- toms and seagrass meadows. Paucity of shelter can cause local demographic bottlenecks (see Cruz et al. 1986, Acosta \& Butler 1997, Butler \& Herrnkind 1997), which can be mitigated with artificial shelters because lobsters will take refuge in many types of natural or man-made structures. This forms the basis of some Caribbean fisheries, wherein lobsters are harvested from beneath large artificial shelters ('casitas') deployed on relatively shallow bottoms (Briones-Fourzán et al. 2000, Cruz \& Phillips 2000). Briones-Fourzán et al. (2007) showed that after deployment of small casitas on experimental sites across the shelter-poor Puerto Morelos reef lagoon (Caribbean coast of Mexico), the density and biomass of juvenile $P$. argus (15 to $50 \mathrm{~mm}$ $\mathrm{CL}$ ) on these sites significantly increased relative to prior levels and to control sites. Casitas did not merely aggregate existing lobsters but actually enhanced them because casitas mitigated paucity of shelter and promoted lobster gregariousness, thus reducing predation-induced mortality and allowing lobsters to exploit food resources more efficiently (BrionesFourzán et al. 2007). In 2000, 2 yr after deployment, lobsters showing gross signs of infection by PaV1 were first detected in the reef lagoon. Huchin-Mian et al. (2008) confirmed the presence of PaV1 in these lobsters through histological sections, transmission electron microscopy (Shields \& Behringer 2004), and PCR analyses (Montgomery-Fullerton et al. 2007).

Because contact rates between healthy and diseased individuals may increase with gregariousness and population density (Lafferty et al. 2004), the potential effects of casitas on transmission and prevalence of PaV1 should be assessed. In the present study, we estimated the prevalence of PaV1 over the entire size range of lobsters (6 to $89 \mathrm{~mm} \mathrm{CL}$ ) in the Puerto Morelos reef lagoon during 2001, 2005, and 2006, and compared habitation patterns of healthy and diseased lobsters between 2001 and 2006. If the prevalence of PaV1 is on the rise, an increase in cohabitation of healthy and diseased lobsters in casitas would be expected owing to the paucity of alternative natural shelter. We also re-examined data on lobster density obtained from casita sites and control sites between 1998 and 2002 to test whether the emergence of PaV1 affected the relative densities between both site groups. If transmission of PaV1 increases with casitas, density on casita sites would be expected to decline more relative to the density on control sites after disease emergence, leading to a convergence of results through time. Finally, during 2006, we compared PaV1 prevalence and habitation patterns between lobsters using casitas in Puerto Morelos and lobsters using experimental casitas deployed in May 2006 in Chinchorro Bank, an oceanic atoll $260 \mathrm{~km}$ south of Puerto Morelos, where casitas had never been used before. 


\section{MATERIALS AND METHODS}

Study area. The Puerto Morelos reef lagoon $\left(20^{\circ} 51^{\prime} \mathrm{N}, 86^{\circ} 53^{\prime} \mathrm{W}\right)$ is a narrow $(<2 \mathrm{~km}$ in width), shallow body of water $(<5 \mathrm{~m}$ in depth) between the shore and an extended fringing reef on the northern Caribbean coast of the Yucatan peninsula (coast of the state of Quintana Roo, Mexico) (Fig. 1). The bottom of the lagoon is mostly calcareous sand stabilized by extensive seagrass meadows dominated by Thalassia testudinum (Ruiz-Rentería et al. 1998), where crevice shelter is sparse and mostly unsuitable for juvenile Panulirus argus (Briones-Fourzán \& Lozano-Álvarez 2001a). Spiny lobster and reef fishes are fished along some portions of the fore-reef but not within the reef lagoon, which is why we chose the reef lagoon for the casita experiment. In addition, the relative importance of fishing activities in Puerto Morelos has been replaced over the last $10 \mathrm{yr}$ by an explosive growth of sea-related tourist activities (Rodríguez-Martínez in press).

Chinchorro Bank (centered at $18^{\circ} 35^{\prime} \mathrm{N}, 87^{\circ} 21^{\prime} \mathrm{W}$ ) is an oceanic atoll-like reef, $48 \mathrm{~km}$ long and $18 \mathrm{~km}$ in its widest part, separated from the southern Quintana Roo coast by a channel $30 \mathrm{~km}$ in width and $700 \mathrm{~m}$ in depth (Fig. 1). The atoll lagoon is $\sim 500 \mathrm{~km}^{2}$ in area, with

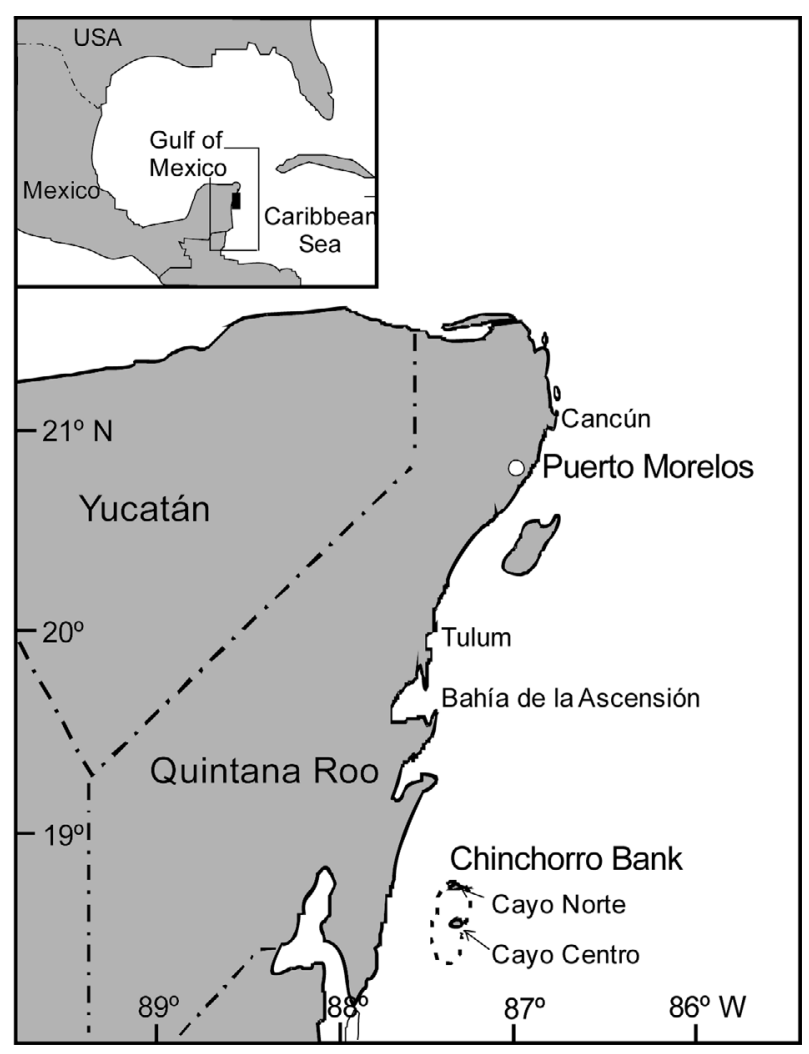

Fig. 1. Study locations along the Caribbean coast of Mexico (state of Quintana Roo) depths ranging from $<2 \mathrm{~m}$ in the northern part to 7-9 $\mathrm{m}$ along the southern section (Jordán \& Martín 1987). Four cays emerge from the atoll lagoon: Cayo Norte (40 ha in surface area) in the north, Cayo Centro (541 ha) in the center, and Cayo Lobos (0.42 ha) in the south. In Chinchorro, there are no permanent human settlements, tourist activities are still incipient, and fishing for spiny lobster, conch, and reef fishes is the most important activity (Sosa-Cordero 2003).

Lobster sampling in Puerto Morelos. The field experiment to test for the enhancement effect of casitas on the population of juvenile Panulirus argus is explained in detail in Briones-Fourzán \& LozanoÁlvarez (2001a) and Briones-Fourzán et al. (2007). Briefly, the setup consisted of 9 sites, 1 ha each and 2.5 to $3.5 \mathrm{~m}$ in depth, distributed throughout the reef lagoon. Starting in April 1997, the entire area of each site was surveyed for lobsters by SCUBA diving on 13 occasions over a period of 16 months. In July 1998, 10 casitas were deployed in each of 5 sites (casita sites). The other 4 sites had no casitas (control sites). Casitas were scaled to harbor juvenile $P$. argus and consisted of a frame made with 5 PVC pipes $3.8 \mathrm{~cm}$ in diameter (3 shorter parallel pipes bolted perpendicularly to 2 longer parallel pipes) and a flat ferrocement slab $1.1 \mathrm{~m}^{2}$ in surface bolted to the frame (entrance height $=$ $3.8 \mathrm{~cm}$; inner height $=7.6 \mathrm{~cm}$ ). Between September 1998 and November 2002, 22 surveys were conducted on all sites. Data recorded during each survey included the number and size (CL in $\mathrm{mm}$ ) of lobsters using each shelter, whether natural or casita, across each site. During 2 periods, one before (April 1997-July 1998) and one after casita deployment (October 1999-July 2001), lobsters were marked with T-bar tags inserted into the dorsolateral muscle between the cephalothorax and the abdomen to assess their growth and movement patterns. All activities, including marking, were conducted underwater.

In October 2000, we noticed that 2 marked lobsters appeared lethargic and showed a pink discoloration over their carapace. In January 2001, 2 additional marked lobsters and 6 unmarked lobsters showed similar signs. Their hemolymph, visible through the thin membrane between the cephalothorax and abdomen, appeared white and it readily seeped through the puncture upon application of the tag (healthy lobsters do not bleed through the puncture because their bluish hemolymph clots very rapidly). It then became evident that the milky, unclotting hemolymph, in conjunction with lethargy and the pink discoloration of the carapace, constituted a syndrome. At that time we did not know the nature of the syndrome, but we carefully examined all lobsters for this syndrome during 6 surveys conducted between January and December 2001. 
After the casita experiment ended (November 2002), the casita sites (but not the control sites) were maintained for other research purposes. From June to December 2005, we collected lobsters from beneath casitas and transferred them to the laboratory, where some were found to show the syndrome, which, as described by Shields \& Behringer (2004), corresponded to the emergent PaV1 disease. In 2006, we established the presence of PaV1 on these lobsters (Huchin-Mian et al. 2008), and between September and December we conducted 3 surveys on casita sites. Because Hurricane Wilma (October 2005) had destroyed the lines delimiting the casita sites, but not the casitas, we limited these surveys to lobsters in casitas. To minimize the possibility of errors, only 3 persons were in charge of examination of lobsters for signs of the disease in all surveys since 2000 .

Lobster sampling in Chinchorro Bank. Within the atoll lagoon of Chinchorro Bank, experimental casitas were deployed in May 2006 on 4 sites around Cayo Centro and 4 sites around Cayo Norte as sampling tools to assess growth and movements of juvenile Panulirus argus (A. Ramírez-Estévez unpubl. data). All sites were $\sim 2 \mathrm{~m}$ in depth and were located on extensive seagrass beds with virtually no natural crevice shelters. Each site measured $3600 \mathrm{~m}^{2}$, but those around Cayo Centro contained 9 casitas each and those around Cayo Norte contained 5 casitas each. Casitas used in Chinchorro Bank consisted of a $1 \mathrm{~m}^{2}$ slab bolted to 2 parallel PVC pipes $10 \mathrm{~cm}$ in diameter (entrance height $=$ inner height $=10 \mathrm{~cm}$ ), and were encased in mesh except for 1 side from which they were pulled out of the water onto a boat to obtain the lobsters. This operation was supervised by 2 divers to ensure that all lobsters in each casita were sampled. The Chinchorro Bank casitas were surveyed on 3 occasions between September 2006 and January 2007. Lobsters found in each casita were counted, measured, and examined for signs of PaV1 by 2 of the 3 persons that conducted the surveys in Puerto Morelos.

Data analyses. We estimated the overall PaV1 prevalence in Panulirus argus in Puerto Morelos in 2001, 2005, and 2006, and in Chinchorro Bank in 2006, and the prevalence by juvenile phase, i.e. within algal juveniles ( $\leq 25.0 \mathrm{~mm} \mathrm{CL}$ ), postalgal juveniles (25.1 to $45.0 \mathrm{~mm} \mathrm{CL}$ ), and subadults (45.1 to $80.0 \mathrm{~mm} \mathrm{CL}$ ), during each year and location. The overall PaV1 prevalence and the prevalence by juvenile phase were compared among years and locations with $\chi^{2}$ contingency tables (Zar 1999).

In Puerto Morelos, habitation patterns of lobsters (i.e. the percentages of healthy and diseased lobsters dwelling alone, cohabiting with healthy conspecifics, or cohabiting with diseased conspecifics) were compared between types of shelter (natural vs. casitas) in
2001. Habitation patterns of lobsters using casitas were compared between 2001 and 2006 in Puerto Morelos, and between Chinchorro Bank and Puerto Morelos in 2006. These data sets were subjected to separate $\chi^{2}$ contingency table analysis.

Lobster density (lobsters ha ${ }^{-1}$ ) in Puerto Morelos was significantly higher on the group of casita sites than on the group of control sites from September 1998 to November 2002 (Briones-Fourzán et al. 2007), but we were interested in testing for a potential change in the relative densities of both site groups before and after emergence of the PaV1 disease. Obviously, the disease would be expected to affect lobsters on both site groups, but if transmission of PaV1 increases with density and gregariousness, then densities on casita sites would be expected to show a greater decrease relative to control sites after emergence due to a greater local mortality and/or emigration of lobsters avoiding casitas harboring diseased conspecifics.

To test this hypothesis, we used a multiple before-after control-impact (MBACI) analysis (Keough \& Mapstone 1995). We considered the entire year 2000 as the period of emergence (not included in the analysis) because, although we first observed lobsters with gross signs of PaV1 in October 2000, we could not ascertain the precise time of emergence. Thus, we regarded the 8 surveys from September 1998 to December 1999 as the 'Before' period and the 9 surveys from January 2001 to November 2002 as the 'After' period (Keough \& Mapstone 1995, Keough \& Quinn 2000). The MBACI analysis was done with an ANOVA. The main (fixed) factors, with 2 levels each, were Site Group (SG, casita sites/control sites) and period (BA, Before/After the disease emergence). Site and Survey were treated as random factors. Site was nested within SG (5 levels for casita sites and 4 levels for control sites) and Survey was nested within BA (8 levels Before and 9 levels After). However, the data were autocorrelated due to the short intervals between some surveys relative to the persistence of Panulirus argus in the reef lagoon (BrionesFourzán et al. 2007). Therefore, we first subjected the data to a repeated-measures ANOVA, from which we obtained the Huyhn-Feldt estimator to adjust the df of Survey and its residuals in order to homogenize the variance-covariance matrix. These adjusted df were used in the MBACI model to compute F-ratios for all terms involving Survey(BA) and its residuals (Keough \& Mapstone 1995, Briones-Fourzán et al. 2007). The final model included the terms SG, BA, SG $\times$ BA, Site $(\mathrm{SG})$, Survey $(\mathrm{BA})$, Site $(\mathrm{SG}) \times \mathrm{BA}$, and $\mathrm{SG} \times \operatorname{Survey}(\mathrm{BA})$. The term of most interest was $\mathrm{SG} \times \mathrm{BA}$, which measures any change associated with emergence of the disease. We further tested for a linear trend in the difference between means (means of casita sites minus means of control sites) through time to test for a potential conver- 
gence (or divergence) between both site groups (Stewart-Oaten et al. 1986, Keough \& Quinn 2000).

We used a separate ANOVA to test for differences in mean densities exclusively on casita sites among 3 periods related to the disease emergence: before (1998-1999), shortly after (2001-2002), and 6 yr after emergence (2006). Although lobster density on casita sites was probably slightly underestimated in the 2006 surveys because it did not include lobsters using natural shelters on these sites (e.g. $3.6 \%$ of lobsters were using natural shelters on casita sites across 2001, see Results), we did not attempt to correct the data. The main factors were Site (random, with 5 levels) and Period (fixed, with 3 levels). Survey was a random factor nested within Period (with 8, 9, and 3 levels, respectively). These data were also previously subjected to a repeated-measures ANOVA to adjust the df of Survey and its residuals. The final model included the terms Site, Period, Site $\times$ Period, and Survey(Period), and the term of most interest was Period.

All tests involving lobster densities were done with the data $\log ($ density +1$)$-transformed to correct for multiplicative effects (reflected in greater differences in means at times when both site groups had higher densities than when both had lower densities, StewartOaten et al. 1986) and heterogeneity of variances (Briones-Fourzán et al. 2007). Also, due to unbalanced sample sizes, the ANOVAs were done using general linear models (Howell 2002).

\section{RESULTS}

\section{Overall prevalence of PaV1}

In Puerto Morelos, we sampled 1211 Panulirus argus in 2001, 213 in 2005, and 469 in 2006, over a size range of 6.2 to $89.2 \mathrm{~mm} \mathrm{CL}$. The size range of diseased lobsters was 11.9 to $58.4 \mathrm{~mm} \mathrm{CL}$, but only $2.7 \%$ of the total lobsters were $\geq 60 \mathrm{~mm}$ CL. The overall PaV1 prevalence (Fig. 2) was $2.7 \%$ in 2001, $7.0 \%$ in 2005 , and $10.9 \%$ in 2006 , and differed significantly among years $\left(\chi^{2}=47.31, \mathrm{df}=2, \mathrm{p}<0.001\right)$. The increase in prevalence was significant between 2001 and $2005\left(\chi^{2}=\right.$ 14.56, $\mathrm{df}=1, \mathrm{p}=0.001)$, but not between 2005 and 2006 $\left(\chi^{2}=2.54, \mathrm{df}=1, \mathrm{p}=0.111\right)$.

In Chinchorro Bank, we sampled 626 lobsters (6.8 to $82.9 \mathrm{~mm} \mathrm{CL}$ ). The size range of diseased lobsters was 12.0 to $67.0 \mathrm{~mm} \mathrm{CL}$, but $11.3 \%$ of the total lobsters were $\geq 60 \mathrm{~mm} \mathrm{CL}$. PaV1 prevalence was $7.4 \%$ (Fig. 2), significantly lower than the 2006 prevalence in Puerto Morelos $\left(\chi^{2}=4.37, \mathrm{df}=1, \mathrm{p}=0.039\right)$, but similar to the 2005 prevalence $\left(\chi^{2}=0.02, \mathrm{df}=1, \mathrm{p}=0.882\right)$ and significantly higher than the 2001 prevalence in Puerto Morelos $\left(\chi^{2}=27.03, \mathrm{df}=1, \mathrm{p}<0.001\right)$.

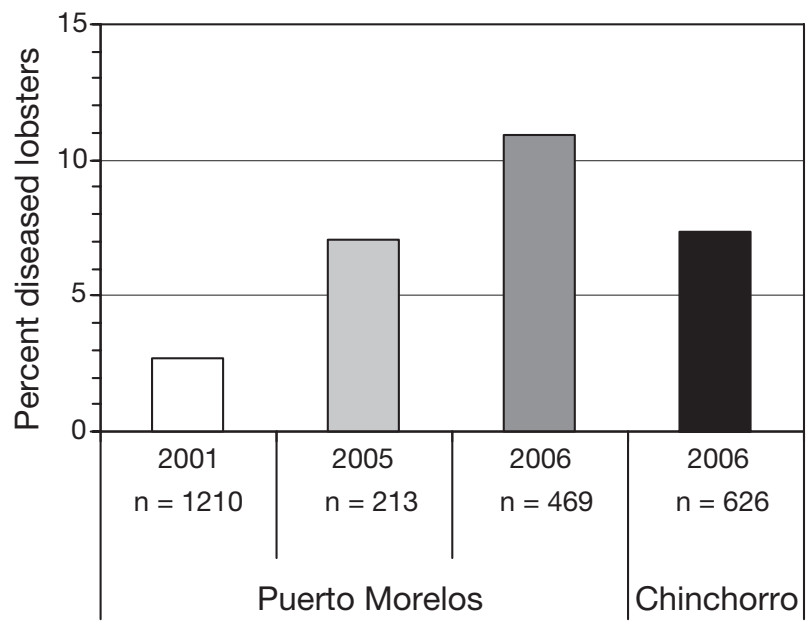

Fig. 2. Panulirus argus. Overall prevalence of PaV1 (Panulirus argus Virus 1) in lobsters on sampling sites across the Puerto Morelos reef lagoon (2001, 2005, and 2006) and the Chinchorro Bank atoll lagoon (2006)

\section{Prevalence of PaV1 by juvenile phase}

In Puerto Morelos, PaV1 prevalence differed significantly among the 3 juvenile phases in $2001\left(\chi^{2}=12.26\right.$, $\mathrm{df}=2, \mathrm{p}=0.002), 2005\left(\chi^{2}=14.21, \mathrm{df}=2, \mathrm{p}<0.001\right)$, and $2006\left(\chi^{2}=16.07, \mathrm{df}=2, \mathrm{p}<0.001\right)$. The most dramatic increase in prevalence occurred within algal juveniles from $2001(1.3 \%)$ to $2005(16.9 \%)\left(\chi^{2}=52.92\right.$, $\mathrm{df}=1, \mathrm{p}<0.001)$, but then remained similar between 2005 and $2006(18.0 \%)\left(\chi^{2}=0.04, \mathrm{df}=1, \mathrm{p}=0.852\right)$ (Fig. 3). In postalgal juveniles, PaV1 prevalence did not differ significantly between 2001 (4.9\%) and 2005

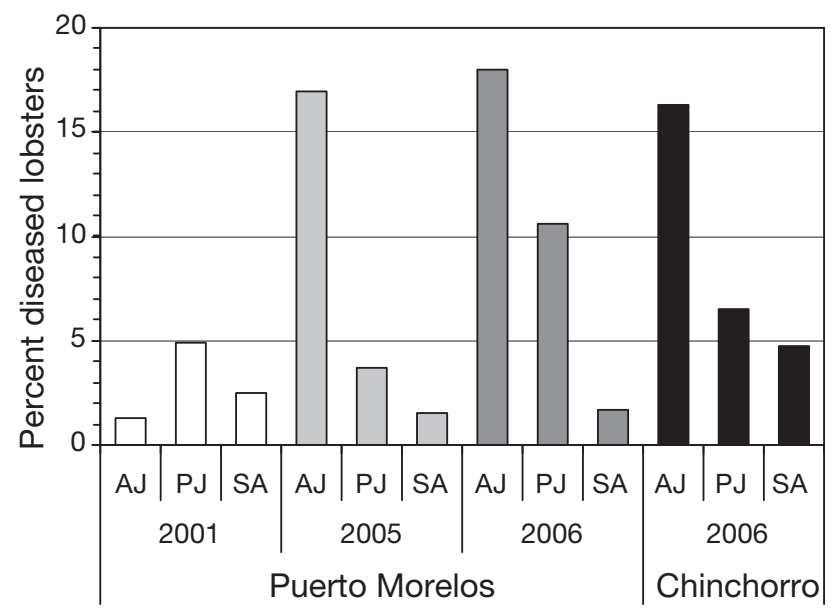

Fig. 3. Panulirus argus. Prevalence of PaV1 in algal juveniles (AJ, 6.0-25.0 $\mathrm{mm}$ carapace length, CL), postalgal juveniles (PJ, 25.1-45.0 mm CL), and subadults (SA, 45.1-80.0 mm CL) in the Puerto Morelos reef lagoon (2001, 2005, and 2006) and in the Chinchorro Bank atoll lagoon (2006) 
$(3.7 \%)\left(\chi^{2}=0.23, \mathrm{df}=1, \mathrm{p}=0.633\right)$, but increased significantly from 2005 to $2006(10.6 \%)\left(\chi^{2}=7.59\right.$, df $=1$, $\mathrm{p}=0.006$ ) (Fig. 3). In contrast, the prevalence in subadults was relatively low and did not differ significantly among the 3 years $(2.5,1.9$, and $1.8 \%$, respectively) ( $\chi^{2}=0.32$, $\mathrm{df}=1, \mathrm{p}=0.853$ ) (Fig. 3).

PaV1 prevalence in Chinchorro Bank was $16.3 \%$ in algal juveniles, $6.5 \%$ in postalgal juveniles, and $4.7 \%$ in subadults (Fig. 3). A $3 \times 2$ contingency table comparing these results with the 2006 results from Puerto Morelos showed that disease occurrence, juvenile phase, and location were all mutually independent factors $\left(\chi^{2}=104.81, \mathrm{df}=7, \mathrm{p}<0.001\right)$. However, the mean size of lobsters was significantly larger in Chinchorro Bank (mean \pm SD: $40.4 \pm 15.0 \mathrm{~mm} \mathrm{CL}$ ) than in Puerto Morelos (34.2 $\pm 14.9 \mathrm{~mm} \mathrm{CL})(t=6.75$, df $=1091, \mathrm{p}<$ 0.001), possibly as a result of the greater entrance height of the Chinchorro Bank casitas. Therefore, to remove the effect of casita size, we compared the prevalence of $\mathrm{PaV} 1$ in each juvenile phase between locations with separate $2 \times 2 \times 2$ contingency tables. These prevalences did not differ significantly (algal juveniles: $\chi^{2}=0.12$, $\mathrm{df}=1, \mathrm{p}=0.734$; postalgal juveniles: $\chi^{2}=2.60, \mathrm{df}=1, \mathrm{p}=0.107$; subadults: $\chi^{2}=2.06$, $\mathrm{df}=1, \mathrm{p}=0.151$ )

\section{Habitation patterns of healthy and diseased lobsters}

In Puerto Morelos, across 2001 we observed 949 healthy and 24 diseased lobsters in casitas (prevalence: $2.5 \%$ ), 35 healthy and 1 diseased lobsters in natural shelters on casita sites (prevalence: $2.9 \%$ ), and 195 healthy and 7 diseased lobsters in natural shelters on control sites (prevalence: 3.6\%). The prevalence did not differ significantly with shelter type on casita sites $\left(\chi^{2}=0.014, \mathrm{df}=1, \mathrm{p}=0.906\right)$ or between casita sites and control sites $\left(\chi^{2}=0.638\right.$, df $=$ $1, \mathrm{p}=0.424)$.

Of the healthy lobsters using natural shelters on control sites, $32.6 \%$ were alone, $63.9 \%$ cohabited with healthy conspecifics, and $3.5 \%$ shared shelters with diseased lobsters (Fig. 4a). Of the healthy lobsters using casitas, 5.7\% were alone, 91.9\% cohabited with other healthy lobsters, and $2.4 \%$ shared casitas with diseased conspecifics (Fig. 4a). These habitation patterns differed significantly with shelter type $\left(\chi^{2}=\right.$ 141.15, df $=2, \mathrm{p}<0.001$ ), with more healthy lobsters cohabiting in casitas than in natural shelters. In contrast, the percentages of diseased lobsters observed in natural shelters that were alone $(62.5 \%)$ or cohabiting with healthy lobsters $(37.5 \%)$ did not differ significantly from those observed in casitas dwelling alone $(44.0 \%)$ or with healthy conspecifics (56.0\%) (Fisher's exact test, $p=0.438$ ) (Fig. $4 b$ ).
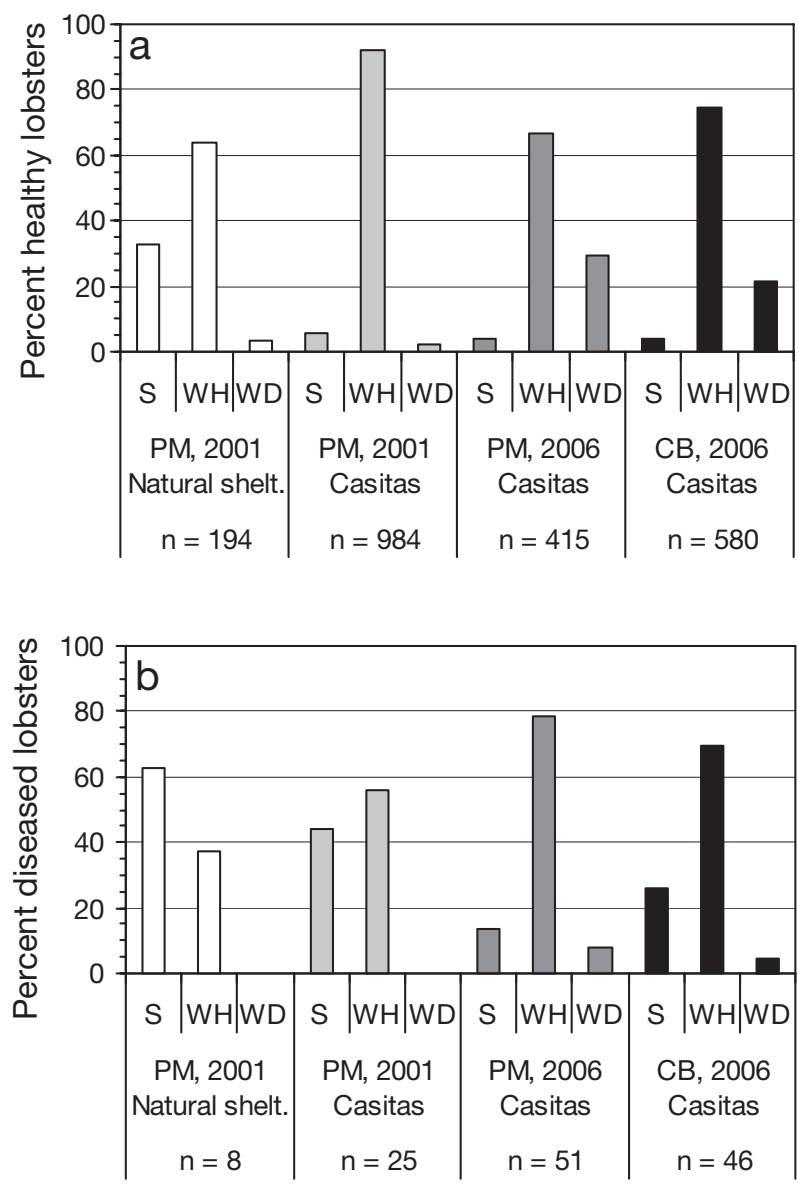

Fig. 4. Panulirus argus. Habitation patterns of (a) healthy and (b) diseased lobsters ( $\mathrm{S}$ : solitary; WH: with healthy conspecifics; WD: with diseased conspecifics) in natural shelters and in casitas in the Puerto Morelos reef lagoon (PM) during 2001, and exclusively in casitas in Puerto Morelos and Chinchorro Bank (CB) during 2006

By 2006, habitation patterns of lobsters using casitas in Puerto Morelos had changed considerably. Of 418 healthy lobsters, $3.9 \%$ were solitary, $66.7 \%$ shared casitas with other healthy lobsters and $29.4 \%$ shared casitas with diseased conspecifics (Fig. 4a), a significantly different habitation pattern from that observed for healthy lobsters using casitas in $2001\left(\chi^{2}=223.12\right.$, $\mathrm{df}=2$, $\mathrm{p}<0.001)$. Also, of the 51 diseased lobsters, $21.6 \%$ were either solitary or sharing casitas with other diseased lobsters, whereas $78.4 \%$ shared casitas with healthy lobsters (Fig. 4b). This habitation pattern also differed significantly from that observed for diseased lobsters in casitas during $2001\left(\chi^{2}=4.10\right.$, df $=1, p=$ 0.043).

Of the 580 healthy lobsters using the Chinchorro Bank casitas, $3.6 \%$ were solitary, $74.7 \%$ cohabited with healthy conspecifics and $21.7 \%$ with diseased lobsters (Fig. 4a). This pattern differed significantly 
from the pattern observed for healthy lobsters in the Puerto Morelos casitas in $2006\left(\chi^{2}=7.94\right.$, df $=2, \mathrm{p}=$ 0.019), with a lower percentage of healthy lobsters sharing casitas with diseased conspecifics in Chinchorro Bank. In contrast, habitation patterns of diseased lobsters did not differ significantly between Chinchorro Bank and Puerto Morelos $\left(\chi^{2}=0.99, \mathrm{df}=1\right.$, $\mathrm{p}=0.319$ ). Of the 46 diseased lobsters observed in Chinchorro Bank, $30.4 \%$ were either alone or sharing casitas with other diseased lobsters and $69.6 \%$ were sharing casitas with healthy lobsters (Fig. 4b).
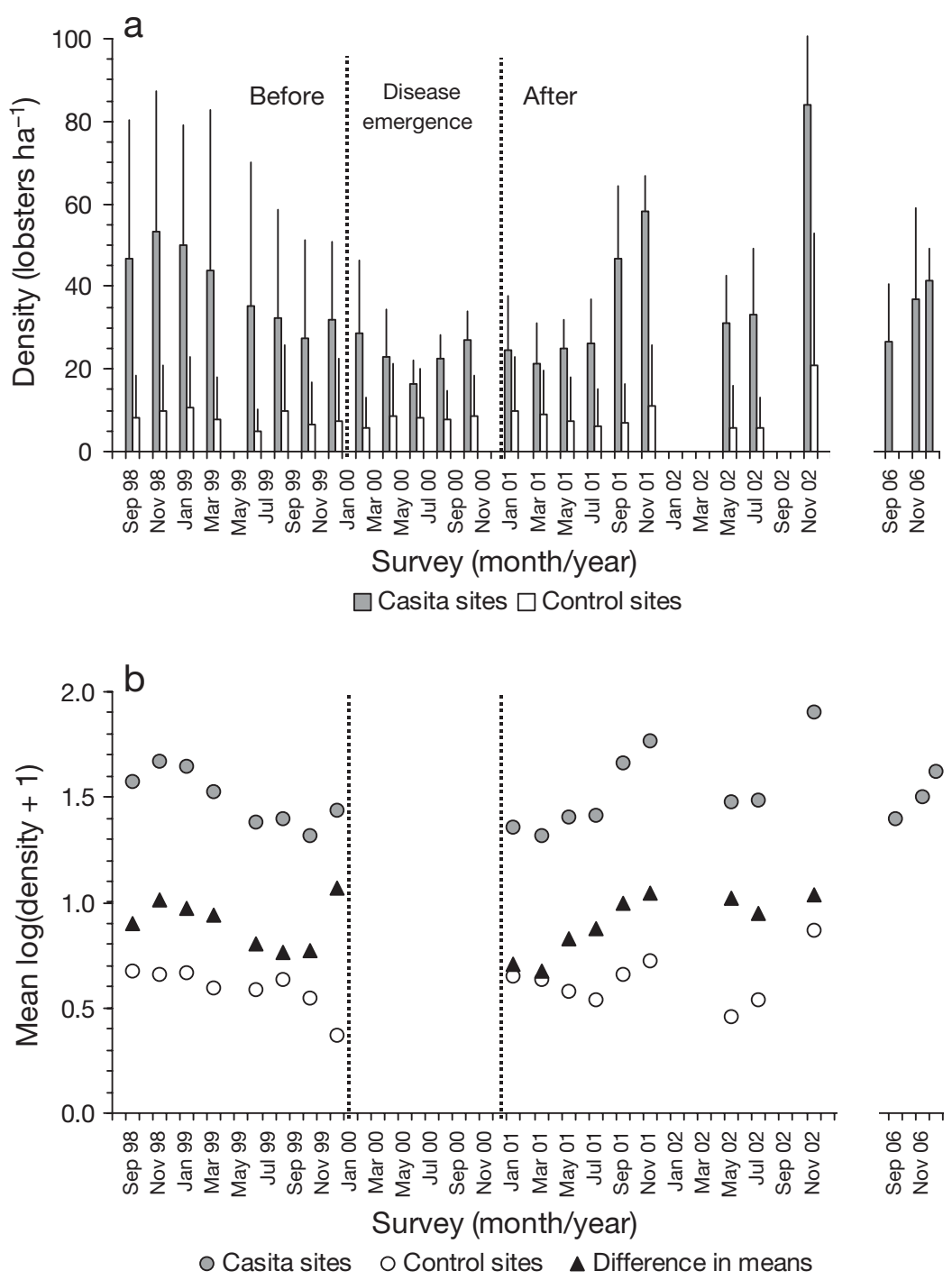

Fig. 5. Panulirus argus. (a) Mean ( \pm SD) densities (lobsters ha ${ }^{-1}$ ) estimated with raw data from surveys in 5 casita sites and 4 control sites across the Puerto Morelos reef lagoon between September 1998 and December 2006. Control sites were not sampled during 2006. (b) Mean densities estimated with data $\log ($ density +1$)$-transformed to test for changes between site groups Before (8 surveys, September 1998-December 1999) and After emergence of PaV1 (9 surveys, January 2001-November 2002) and for a trend through time of the difference in means (means from casita sites minus means from control sites)

\section{Changes in density of juveniles (Puerto Morelos)}

Fig. 5a shows the mean lobster densities ( \pm SD) by site group and survey estimated with the raw data and Fig. 5b shows the mean densities of the log-transformed data used in the statistical analyses. Results from the MBACI model comparing densities between were those of SG (i.e. the effect of casitas) and S(SG) (Table 1). In particular, the $\mathrm{SG} \times \mathrm{BA}$ interaction was not significant $(\mathrm{p}=0.994)$, indicating that the relative densities on both site groups did not change significantly before or after emergence of the disease. This was also shown by the non-significant trend through time of the difference in means ( $r=0.178, p=0.495$ ) (Fig. 5b). Based on the raw data, the mean density on the group of casita sites relative to the group of control sites was $492 \%$ higher before (mean \pm SD: $40.1 \pm 9.6$ lobsters ha ${ }^{-1}$ versus $8.2 \pm 1.8$ lobsters $\mathrm{ha}^{-1}$ ) and $423 \%$ higher after $\left(39.0 \pm 20.5\right.$ lobsters ha ${ }^{-1}$ versus $8.8 \pm 4.7$ lobsters ha ${ }^{-1}$ ) emergence of the disease (Fig. 5a). However, across 2000 (the putative period of emergence), the mean density on casita sites (23.5 \pm 4.8 lobsters $\mathrm{ha}^{-1}$ ) was lower than before or after emergence (Fig. 5a), but was still $303 \%$ higher than on control sites $(7.7 \pm$ 1.2 lobsters ha ${ }^{-1}$ ).

Results from the analysis comparing lobster densities exclusively on casita sites showed that the effects of Site $\times$ Period and Survey(Period) were significant, but the effects of Site and Period were not significant (Table 2). Therefore, by 2006 the density of lobsters increased on some sites and decreased on others, but the mean density $(35.1 \pm 7.5$ lobsters $\mathrm{ha}^{-1}$, not including natural shelters) did not differ significantly from the mean densities before and shortly after emergence of the disease (which included natural shelters across casita sites).

\section{DISCUSSION}

The PaV1 disease emerged in the Puerto Morelos reef lagoon during 2000, 2 yr after deployment of casitas on some experimental sites. During 2001, PaV1 prevalence was low on all sites (i.e. casita 
Table 1. Panulirus argus. Analysis to test for changes in mean density of lobsters (lobsters ha ${ }^{-1}$, data $\log ($ density +1 )-transformed) between 2 Site groups (SG; 5 casita sites, 4 control sites), Before (8 surveys, September 1998-December 1999) and After (9 surveys, January 2001-November 2002) emergence (BA: Before/After) of the PaV1 disease in the Puerto Morelos reef lagoon. Degrees of freedom of Survey, Residual, and their interactions were adjusted with the Huynh-Feldt estimato previously obtained from a repeated-measures ANOVA

\begin{tabular}{|lccccc|}
\hline Effect & $\begin{array}{c}\text { Sum of } \\
\text { squares }\end{array}$ & df & MS & $F$ & $p$ \\
\hline Intercept & 173.186 & 1 & 173.186 & 52.093 & $<0.001$ \\
Site group & 30.725 & 1 & 30.725 & 9.242 & 0.019 \\
Before/After & 0.051 & 1 & 0.051 & 0.219 & 0.654 \\
SG $\times$ BA & 0.00002 & 1 & 0.00002 & 0.00007 & 0.994 \\
Site(SG) & 23.272 & 7 & 3.325 & 14.322 & 0.001 \\
Survey(BA) & 2.223 & 5 & 0.445 & 3.954 & 0.079 \\
SG $\times$ Survey(BA) & 0.562 & 5 & 0.112 & 0.935 & 0.410 \\
Site(SG) $\times$ BA & 1.625 & 7 & 0.232 & 1.930 & 0.470 \\
Residual & 4.450 & 15 & 0.120 & & \\
\hline
\end{tabular}

Table 2. Panulirus argus. Analysis to test for changes in mean density of lobsters (lobsters ha ${ }^{-1}$, data $\log ($ density +1 )-transformed) on 5 casita sites among 3 periods: before (8 surveys, September 1998-December 1999), shortly after (9 surveys, January 2001-November 2002) and 6 yr after (3 surveys, September-December 2006) emergence of the PaV1 disease in the Puerto Morelos reef lagoon. Degrees of freedom of Survey, Residual, and their interactions were adjusted with the Huynh-Feldt estimator previously obtained from a repeated-measures ANOVA

\begin{tabular}{|lccccc|}
\hline Effect & $\begin{array}{c}\text { Sum of } \\
\text { squares }\end{array}$ & df & MS & $F$ & $p$ \\
\hline Intercept & 156.596 & 1 & 156.596 & 209.895 & $<0.001$ \\
Site & 2.154 & 4 & 0.538 & 2.924 & 0.148 \\
Period & 0.177 & 2 & 0.088 & 0.479 & 0.631 \\
Survey(Period) & 2.210 & 12 & 0.184 & 6.224 & $<0.001$ \\
Site $\times$ Period & 1.059 & 8 & 0.132 & 4.474 & $<0.001$ \\
Residual & 1.391 & 47 & 0.030 & & \\
\hline
\end{tabular}

sites and control sites), as was the percentage of healthy lobsters cohabiting with diseased conspecifics, and up to November 2002 the relative densities on each site group did not change significantly before (1998-1999) or after (2001-2002) emergence of the disease.

Lobster densities, though, showed a greater relative decrease on casita sites than on control sites across the putative period of emergence (i.e. the year 2000), but whether this decrease was due to a greater impact of the disease on lobsters across casitas sites at the time of emergence or to other factors is difficult to ascertain. For example, changes in local densities could also be driven by other factors, such as previous levels of postlarval settlement and local availability of small juveniles. These factors vary widely in Puerto Morelos (Briones-Fourzán \& Lozano-Álvarez 2001a,b, BrionesFourzán et al. 2008) and are possibly more strongly realized on shelter-enhanced casita sites than on shelter-poor control sites (hence contributing to the multiplicative effects) (Briones-Fourzán et al. 2007). But in 2006, despite the significant increases in PaV1 prevalence and in the level of cohabitation of healthy and diseased lobsters, mean lobster densities on casita sites had not changed significantly from the corresponding values obtained before and shortly after emergence of the disease.

In Chinchorro Bank, 4 to 8 mo after casita deployment, PaV1 prevalence was $7.4 \%$ and $21.7 \%$ of healthy lobsters shared casitas with diseased conspecifics. These levels were lower than the corresponding levels observed in Puerto Morelos during 2006, but were much higher than those observed during 2001, shortly after the disease emerged in Puerto Morelos. These findings, in conjunction with the similar prevalence by juvenile phase in both locations in 2006, suggest that the disease also emerged in Chinchorro Bank some time ago.

Our results would not appear to support the notion of a potential increase in transmission of PaV1 with casitas, i.e. that the increasing trend in PaV1 prevalence in Puerto Morelos could be related to the use of casitas. For example, the prevalence in Chinchorro Bank and Puerto Morelos during 2005 and 2006 was similar to the 2001-2006 average prevalence in Florida Bay (6-8\%, Behringer et al. 2006), where casitas have never been used. Nevertheless, our results are far from conclusive because we had no data from control sites with which to contrast data from casita sites during 2005-2006 and have no knowledge of prevalence in Chinchorro Bank before 2006.

On the other hand, little is known of the dynamics of this disease in wild populations of Panulirus argus. It is possible that some lobsters are more resistant to infection than others, as suggested by the observations of Matthews \& Maxwell (2007) that some juvenile $P$. argus confined in experimental tanks with infected conspecifics for more than $1 \mathrm{yr}$ never contracted the disease. In particular, the increasing percentages of healthy lobsters sharing casitas with diseased lobsters between 2001 and 2006 appear inconsistent with the results of the laboratory trials of Behringer et al. (2006), wherein healthy lobsters clearly avoided shel- 
ters harboring a diseased conspecific. A possible explanation for these apparently contradictory findings is that avoidance of diseased lobsters by healthy lobsters in the wild is modulated by local availability of shelter and predation risk. Thus, across shelter-limited habitats such as our experimental sites on Puerto Morelos and Chinchorro Bank, healthy lobsters may make a trade-off between avoiding diseased conspecifics and avoiding predation risk. And the large shelter area provided by casitas $\left(1 \mathrm{~m}^{2}\right)$ may allow healthy and diseased lobsters to share these dens without physical contact.

However, even if the disease does not have a meaningful impact on lobster density on areas enhanced with casitas, other potential effects of the virus on these lobsters are yet to be investigated (e.g. changes in growth rates, nutritional status, or resistance to stress) (Lightner \& Redman 1998). Given the extensive use of large casitas in many Caribbean fisheries and the potential use of small casitas to enhance juvenile populations, these issues require far more studies.

Our study supports previous findings that PaV1 mainly affects juvenile Panulirus argus (Shields \& Behringer 2004, Behringer et al. 2006, Butler et al. 2008), but PaV1 prevalence within adults, which use different habitats than juveniles, has not been regularly assessed. Moreover, wild lobsters in the initial stages of infection may be undetected. Behringer et al. (2006) found that lobsters inoculated with infected hemolymph take $6 \mathrm{wk}$ to develop gross signs of infection. Also, the existence of potential carriers not showing signs of the disease (e.g. Lightner \& Redman 1998, Motte et al. 2003) remains unknown. Therefore, it is essential that the presence of PaV1 is clearly established and monitored across the entire benthic phases in local populations of $P$. argus. This would also allow the generation of time series to investigate the potential effects of natural and anthropogenic stressors on the disease dynamics (Hayes et al. 2001, Harvell et al. 2002, Lafferty et al. 2004). Equally important is to establish the presence of PaV1 in other Caribbean locations, as many diseases and syndromes have a Caribbean-wide occurrence (see Lessios et al. 1984, Harvell et al. 2002), which may be enhanced by the relatively high connectivity of marine populations across this region. The use of non-destructive assessments of PaV1 with specific PCR detection assays (e.g. Montgomery-Fullerton et al. 2007) would be a huge step towards accomplishing these endeavors.

Acknowledgements. We thank F. Negrete-Soto and C. Barradas-Ortiz for their invaluable technical support in the field. E. Magallón-Gayón, K. Baeza-Martínez, C. Aguilar-Cardozo, and G. Escobedo provided additional help. Authorities of the Biosphere Reserve of Chinchorro Bank provided logistic sup- port in Chinchorro Bank. Annual permits to conduct lobster surveys were issued by Comisión Nacional de Acuacultura y Pesca, México.

\section{LITERATURE CITED}

Acosta CA, Butler MJ (1997) Role of mangrove habitat as a nursery for juvenile spiny lobster, Panulirus argus, in Belize. Mar Freshw Res 48:721-727

Behringer DC, Butler MJ, Shields JD (2001) The first viral disease reported in lobsters. Lobster Newsl 14:1-3

Behringer DC, Butler MJ, Shields JD (2006) Avoidance of disease by social lobsters. Nature 441:421

Briones-Fourzán P, Lozano-Álvarez E (2001a) Effects of artificial shelters (Casitas) on the abundance and biomass of juvenile spiny lobsters Panulirus argus in a habitat-limited tropical reef lagoon. Mar Ecol Prog Ser 221:221-232

Briones-Fourzán P, Lozano-Álvarez E (2001b) The importance of Lobophora variegata (Phaeophyta: Dictyotales) as a habitat for small juveniles of the spiny lobster, Panulirus argus (Decapoda: Palinuridae) in a tropical reef lagoon. Bull Mar Sci 68:207-219

Briones-Fourzán P, Lozano-Álvarez E, Eggleston DB (2000) The use of artificial shelters (casitas) in research and harvesting of Caribbean spiny lobsters in Mexico. In: Phillips BF, Kittaka J (eds) Spiny lobsters: fisheries and culture, 2nd edn. Fishing News Books, Oxford, p 420-446

Briones-Fourzán P, Lozano-Álvarez E, Negrete-Soto F, Barradas-Ortiz C (2007) Enhancement of juvenile Caribbean spiny lobsters: an evaluation of changes in multiple response variables with the addition of large artificial shelters. Oecologia 151:401-416

Briones-Fourzán P, Candela J, Lozano-Álvarez E (2008) Postlarval settlement of the spiny lobster Panulirus argus along the Caribbean coast of Mexico: patterns, influence of physical factors, and possible sources of origin. Limnol Oceanogr 53:970-985

> Butler MJ, Herrnkind WF (1997) A test of recruitment limitation and the potential for artificial enhancement of spiny lobster (Panulirus argus) populations in Florida. Can J Fish Aquat Sci 54:452-463

Butler MJ, Behringer DC, Shields JD (2008) Transmission of Panulirus argus virus 1 (PaV1) and its effect on the survival of juvenile Caribbean spiny lobster. Dis Aquat Org 79:173-182

Childress MJ, Herrnkind WF (1996) The ontogeny of social behaviour among juvenile Caribbean spiny lobsters. Anim Behav 51:675-687

Childress MJ, Herrnkind WF (2001) The guide effect influence on the gregariousness of juvenile Caribbean spiny lobsters. Anim Behav 62:465-472

Cruz R, Phillips BF (2000) The artificial shelters (pesqueros) used for spiny lobster (Panulirus argus) fisheries in Cuba. In: Phillips BF, Kittaka J (eds) Spiny lobsters: fisheries and culture, 2nd edn. Fishing News Books, Oxford, p 400-419

Cruz R, Brito R, Díaz E, Lalana R (1986) Ecología de la langosta (Panulirus argus) al SE de la Isla de la Juventud. I. Colonización de arrecifes artificiales. Rev Invest Mar 7:3-17

> Dolan TW, Butler MJ (2006) The adaptive value of aggregation among juvenile Caribbean spiny lobster: an evaluation using individual-base modeling. J Crustac Biol 26: 565-578

Evans LH, Jones JB, Brock JA (2000) Diseases of spiny lobsters. In: Phillips BF, Kittaka J (eds) Spiny lobsters: fisheries and culture, 2nd edn. Fishing News Books, Oxford, p 586-600 
Harvell CD, Mitchell CE, Ward JR, Altizer S, Dobson AP, Ostfeld RS, Samuel MD (2002) Climate warming and disease risks for terrestrial and marine biota. Science 296: $2158-2162$

Hayes ML, Bonaventura J, Mitchell TP, Prospero JM, Shinn EA, Van Dolah F, Barber RT (2001) How are climate and marine biological outbreaks functionally linked? Hydrobiologia 460:213-220

Howell DC (2002) Statistical methods for psychology, 5th edn. Duxbury, Pacific Grove, CA

> Huchin-Mian JP, Rodríguez-Canul R, Arias-Bañuelos E, Simá-Álvarez R, Pérez-Vega JA, Briones-Fourzán $P$, Lozano-Álvarez E (2008) Presence of Panulirus argus Virus 1 (PaV1) in juvenile spiny lobsters Panulirus argus from the Caribbean coast of Mexico. Dis Aquat Org 79:153-156

Jordán E, Martín E (1987) Chinchorro: morphology and composition of a Caribbean atoll. Atoll Res Bull 310:1-34

Keough MJ, Mapstone BD (1995) Protocols for designing marine ecological monitoring programs associated with BEK mills. National Pulp Mills Res Prog Tech Rep No. 11. CSIRO, Canberra

Keough MJ, Quinn GP (2000) Legislative vs. practical protection of an intertidal shoreline in southeastern Australia. Ecol Appl 10:871-881

Lafferty KD, Porter JW, Ford SE (2004) Are diseases increasing in the ocean? Annu Rev Ecol Evol Syst 35:31-54

Lessios HA, Robertson DR, Cubit JD (1984) Spread of Diadema mass mortality through the Caribbean. Science 226:335-337

Li C, Shields JD (2007) Primary culture of hemocytes from the Caribbean spiny lobster, Panulirus argus, and their susceptibility to Panulirus argus Virus 1 (PaV1). J Invertebr Pathol 94:48-55

Lightner DV, Redman MR (1998) Shrimp diseases and current diagnostic methods. Aquaculture 164:201-220

Lipcius RN, Eggleston DB (2000) Ecology and fishery biology

Editorial responsibility: Grant Stentiford, Weymouth, UK of spiny lobsters. In: Phillips BF, Kittaka J (eds) Spiny lobsters: fisheries and culture, 2nd edn. Fishing News Books, Oxford, p 1-41

Matthews TR, Maxwell KE (2007) Growth and mortality of captive Caribbean spiny lobsters, Panulirus argus, in Florida, USA. Proc Gulf Carib Fish Inst 58:377-386

- Montgomery-Fullerton MM, Cooper RA, Kauffman KM, Shields JD, Ratzlaff RE (2007) Detection of Panulirus argus Virus 1 in Caribbean spiny lobsters. Dis Aquat Org 76:1-6

Motte E, Yugcha E, Luzardo J, Castro F and others (2003) Prevention of IHHNV vertical transmission in the white shrimp Litopenaeus vannamei. Aquaculture 219:57-70

> Nevitt G, Pentcheff ND, Lohmann KJ, Zimmer RK (2000) Den selection by the spiny lobster Panulirus argus: testing attraction to conspecific odors in the field. Mar Ecol Prog Ser 203:225-231

Ratchford SG, Eggleston DB (1998) Size- and scale-dependent chemical attraction contribute to an ontogenetic shift in sociality. Anim Behav 56:1027-1034

Rodríguez-Martínez RE (in press) Community involvement in marine protected areas: the case of Puerto Morelos reef, México. J Environ Manage

Ruiz-Rentería F, van Tussenbroek BI, Jordán-Dahlgren E (1998) Puerto Morelos, Quintana Roo, Mexico. In: Kjerfve B (ed) CARICOMP: Caribbean coral reef, seagrass, and mangrove sites. UNESCO, Paris, p 57-66

Shields JD, Behringer DC (2004) A new pathogenic virus in the Caribbean spiny lobster Panulirus argus from the Florida Keys. Dis Aquat Org 59:109-118

Sosa-Cordero E (2003) Trends and dynamics of the spiny lobster, Panulirus argus, resource in Banco Chinchorro, Mexico. Bull Mar Sci 73:203-217

Stewart-Oaten A, Murdoch WW, Parker KR (1986) Environmental impact assessment: 'pseudoreplication' in time? Ecology 67:924-940

Zar JH (1999) Biostatistical analysis, 4th edn. Prentice-Hall, Upper Saddle River, NJ

Submitted: November 7, 2007; Accepted: March 17, 2008 Proofs received from author(s): June 26, 2008 